\title{
Нагорна Г.О.
}

ORCID iD 0000-0002-2541-3165

\section{ДОСЛІДНИЦЬКА ДІЯЛЬНІСТЬ ЯК ФАКТОР ФОРМУВАННЯ МУЗИЧНОГО МИСЛЕННЯ ОСОБИСТОСТІ}

У статті висвітлено проблему організації дослідницької діяльності студентів музичних вишів як головного фактора, що впливає на сформованість їхнього музичного мислення. Для досягнення цієї мети здійснювалось перетворення музичної освіти як цілісного процесу музичного дослідження на основі ресрлексивного моделювання, а музичного дослідження як дослідницької самокритичної діяльності музиканта. Було встановлено, що тільки при системному вивченні майбутніми музикантами фактів, явищ, обставин музичного процесу можливо виробити узагальнені вміння визначати і досягати мети музичного дослідження, виробляти ціннісно-методологічну стратегію і тактику відношень у прочесі взаємодії з предметами цього дослідження, оцінювати результати своєї дослідницької діяльності. Окрім цього, формування музичного мислення особистості спрямовувалось на досягнення нею професійної розумності як універсальної якості, що забезпечує розуміння і осмислення чілісного прочесу музичного дослідження та зумовлює оволодіння чіннісно-методологічною культурою.

Ключові слова: дослідницька діяльність, особистісно-діяльнісний підхід, музичне мислення, професійна розумність, рефлексивне управління.

() Нагорна Г.О., 2018

Визначення проблеми. Відомо, що в процесі вишівської підготовки рефлексивному мисленню майбутнього педагога-музиканта, як і діалогу, відводиться незначне місце, хоча це видається більш важливим, ніж управління студентами з боку викладача закладу вищої освіти (3ВО). Прийнято вважати, що дослідницький аспект у музичній освіті, який існує в навчанні майбутніх музикантів, сьогодні забезпечує просте накопичення знань. Ми ж уважаємо за необхідне змінити сам підхід до музичної освіти і представити її як цілісний процес музичного дослідження, а останнє - як дослідницьку самокритичну діяльність музиканта. У цьому процесі студенти є членами дослідницьких дорадчих груп, беруть участь у діалогічному спілкуванні, постійно самокоректують свою діяльність. Тому актуальність окресленої проблеми не викликає сумнівів.

Мета й завдання дослідження. Перетворення музичної освіти як цілісного процесу музичного дослідження здійснювалося на основі рефлексивного моделювання і стало рушійною силою процесу формування музичного мислення особистості. Тому мета дослідження полягала в організації дослідницької діяльності студентів музичних вишів як основного фактора, що впливає на сформованість їхнього музичного мислення.

На нашу думку, тільки при системному дослідженні майбутніми музикантами фактів, явищ, обставин музичного процесу можливо виробити узагальнені вміння визначати і досягати мети музичного дослідження, виробляти ціннісно-методологічну стратегію і тактику відношень у процесі взаємодії з предметами музичного дослідження, самооцінювати результати своєї дослідницької діяльності.

Окрім цього, формування і розвиток музичного мислення особистості спрямовувались на досягнення нею професійної розумності як універсальної якості, що забезпечує розуміння й осмислення цілісного процесу музичного дослідження, зумовлює оволодіння ціннісно-методологічною культурою.

Виходячи з поставленої мети, розв'язувалися такі завдання дослідження:

- обгрунтувати методологію критеріально-ціннісного підходу як провідної стратегії особистісно-діяльнісного підходу до студентів музичних вишів у процесі формування у них музичного мислення;

- виявити види дослідницької діяльності i їх взаємозв’язок на основі принципів єдності загального й особливого, простого і складного;

- розкрити дослідницьку самокритичну діяльність майбутнього музиканта як критерій істинності його музичного мислення, спрямованого на оволодіння професійною розумністю особистості;

- проаналізувати роль рефлексивного управління формуванням музичного мислення 
особистості та цілісним процесом музичного дослідження.

Аналіз останніх досліджень та публікацій. Проблема вивчення діяльності особистості в цілому і дослідницької зокрема знайшла широке відображення в теорії і практиці музичної освіти $(1 ; 3-4 ; 7)$.

Зокрема, у процесі розробки основ дослідницької діяльності педагога-музиканта розкрито сутність, особливості та види навчально-дослідницької діяльності (1). Саме поняття «дослідницька діяльність» визначається як «... прояв здатності мислити, самостійно порівнювати, зіставляти різні точки зору, вступати в дискусію, виявляти власну позицію, науково обгрунтовувати і професійно відстоювати іiі» (1, с. 5). На думку автора, сутність навчально-дослідницької діяльності педагога-музиканта полягає в тому, щоб «... вчитися досліджувати самого себе, аналізувати (рефлексувати) свою професійну діяльність, а також діяльність колег і вихованців, осмислювати ефективність застосовуваних методів викладання, аналізувати результати конструювання змісту музичної освіти і намагатися формулювати для себе вихідні установки цього дослідження» (1, с. 9). Таким чином, дається установка «... на пізнання і поглиблення уявлень про основи музичного навчання, виховання і розвитку особистості, на вдосконалення принципів і методів музично-педагогічного дослідження, на ефективну практику формування музичної культури тих, що навчаються, на підвищення своєї професійної компетентності» $(1$, с. 9$)$.

Психологічне обгрунтування музично-виконавської діяльності особистості полягає у виявленні психологічних особливостей сприйняття, збереження і переробки музичної інформації, безпосереднього виконання музичного твору, концертного виступу (7). При цьому дається загальна психологічна характеристика діяльності, яка визначається як «... специфічно людська, регульована свідомістю “внутрішня” (психічна) і “зовнішня" (рухова) активність, спрямована на досягнення свідомо поставленої мети» (7, с. 9). На основі розробленої структури діяльності музиканта-виконавця, що складається з перцептивного, мнемічного, розумового, мажинітивного і рухового компонентів, представляються методи діагностики здібностей і виконавських якостей музиканта, розкривається процес формування професійної майстерності музиканта-виконавця (7).

Заслуговує на увагу трактування музичного інтерпретування як організованої інтелектом творчої діяльності музичного мислення, «... яка спрямована на розкриття виразно-смислових можливостей музичного твору» (3, с. 32).

Викликає інтерес визначення діяльно-творчого компонента структури духовної культури як особистісного надбання, який виражає спроможність «... не тільки споживати, а й діяти, творити, втілювати в життя власні переконання, містить орієнтири духовної самореалізації особистості, зокрема в процесі мистецької діяльності» (4, с. 33).

Ми вважали за необхідне виділити значущість особистісно-діяльнісного підходу до студентів у ході дослідження та формування у них музичного мислення, що забезпечує особистісну суб’єктну позицію майбутнього музиканта, на основі якої проявляється ставлення до студента як до унікальної особистості.

Методологія дослідження. Провідною стратегією щодо особистісно-діяльнісного підходу є реалізація методології критеріально-ціннісного підходу як одного з умов досягнення соціально заданої мети музичної освіти - професійної розумності музиканта. Розробка такої стратегії можлива за умови орієнтації на суб'єктний розвиток особистості, спрямований на формування розсудливої і творчої індивідуальності музиканта. Остання асоціюється з самоповагою і продуктивністю особистості студента. Така орієнтація можлива на основі особистісно-діяльнісного підходу, що поєднує в собі індивідуально-автономний і полісуб'єктний (діалогічний) підходи до студентів, коли в педагогічну взаємодію викладачів музичних ЗВО й студентів включається їхній особистісний досвід. Таким чином, процес формування у майбутніх музикантів професійного мислення стає персоналізованим, тобто протікає на основі особливого ставлення до студента як до найвищої цінності й неповторної особистості.

В основу спеціальної методології покладено принципи єдності раціонального й творчого, загального й особливого, простого і складного, індивідуального та соціального, особистісного й діяльнісного підходів.

Виклад основного матеріалу. Основним критерієм істинності професійного мислення майбутнього музиканта $€$ його діяльність, точніше ієрархія видів діяльності, де кожний наступний містить у собі попередній, де дослідницька самокритична діяльність педагога-музиканта як цілісна єдність об'єднує множину видів. У цьому полягає прояв принципів єдності загального й особливого, простого і складного. Останнє виражається в тому, що дослідницька діяльність як ціле складається з розсудливої, організаційно-інформаційної, творчо-перетво- 
рювальної, оцінювальної діяльності. Принцип єдності загального й особливого виражається ступенем прояву цих видів діяльності, відображеної як рівнем кількісного, так і рівнем якісного наповнення, коли на верхівці ієрархї стоїть оцінювання як вид діяльності, що узагальнює в собі все попереднє дослідження.

Вивчення майбутніми музикантами фактів, явищ, обставин цілісного музичного процесу здійснювалося різними шляхами на основі алгоритмічного й евристичного підходів. Так, студенти розглядали предмети свого дослідження з точки зору їх контекстів, створюючи допоміжні схеми або впорядковані системи, що містять відношення «частина - ціле», «засоби - мета», «причини - наслідок».

Відношення загального характеру, що виникають в музичних явищах і обставинах, не закінчуються переліченими. Їх різновиди $є$ невичерпні й аналізуються. Наприклад, П. Сопер пропонує до застосування такі універсальні схеми при розробці виступів, як теорія і практика, борг і вигода, факт і його практичне значення, зло і подолання його (5). Тому можна уявити, яка кількість відношень специфічного характеру виникає в музичних явищах і обставинах.

У теорії Дж. Дьюї виокремлюють п’ять етапів дослідження на основі методу розумності: «1) почуття утруднення; 2) визначення його змісту і меж; 3) створення гіпотези про можливе вирішення проблем; 4) критичне виведення наслідків; 5) спостереження, що веде до прийняття або відхилення гіпотези» (6, с. 187).

Рішення алгоритмів безпосередньо пов'язано $з$ проблемою, яка вирішується.

Алгоритм (від латин. algorithmi) - «... припис, що задає на основі системи правил послідовність операцій, точне виконання яких дозволяє вирішувати завдання певного класу» (2, c. 13). Застосовується для організації процесу управління формуванням музичного мислення майбутнього фахівця шляхом виконання приписів у дослідницькій діяльності музиканта.

Проблема - «... усвідомлення суб'єктом неможливості розв'язати труднощі і протиріччя, що виникли в даній ситуації, засобами наявності знання і досвіду» (2, с. 13).

Ситуація є тим джерелом, з якого виникає проблема, завдання. У психології стверджується, що ситуація як психологічна категорія відображає «... лише початкову стадію розумової взаємодії суб’єкта з об’єктом, пов’язану з породженням пізнавального мотиву і висуненням попередніх гіпотез щодо способів розв'язання проблемної ситуації» (2, с. 259). Згодом ситуація може перерости або в проблему, або в завдання. Перетворення ситуації в завдання як знакову іiі модель, за якою можна здійснювати дослідження цілісного музичного процесу, є ознакою творчого мислення особистості. Майбутні музиканти розв'язують завдання і проблеми, висловлюючи свої ідеї, судження, умовиводи, розмірковуючи про об'єкти, суб’єкти, факти, обставини, ситуації процесу розвитку музичного мистецтва, порівнюючи їх між собою, спираючись на стандарти. Таким чином, згідно з психологічними установками, основним сутнісним елементом ситуації $€$ суб’єкт, у завданні на перший план виходить знаковий об’єкт, у проблемі ж - протиріччя між наявними сутностями (2, с. 259). 3 другого боку, сама проблемна ситуація позначається як: «1) ситуація, для оволодіння якою індивід або колектив зобов'язані знайти і використати нові для себе засоби і способи діяльності; 2) психологічна модель умов породження мислення на основі ситуативно виникаючої пізнавальної потреби, форма зв'язку суб'єкта з об’єктом пізнання» (2, с. 259).

Системна реалізація особистісно-діяльнісного підходу як способу функціонування критеріально-ціннісного підходу зумовила не тільки введення в процес формування музичного мислення майбутнього педагога-музиканта системи багаторівневих засобів, а й дала змогу розглядати дослідницьку самокритичну діяльність студента як критерій істинності його музичного мислення. Уміння, що виражають цю діяльність, є ознаками прояву ціннісних показників зазначеного мислення. Це, зокрема, такі вміння: вибирати мету дослідження; знаходити або творчо створювати тактику відношень; виробляти ціннісно-методологічну стратегію відношень; оцінювати, самооцінювати доречність, надійність, силу вироблених стратегії і тактики відношень у процесі взаємодії з предметами музичного дослідження. 3 огляду на це навчання розумовим умінням здійснювалося на лекційних, практичних та індивідуальних заняттях. Не менш важливим є спецкурс «Методологія і технологія музичного мислення особистості». Ми виходили з того, що в ході формування зазначеного мислення максимально більша кількість дисциплін має інтегруватись у бік посилення питань музичного дослідження. Систематизуючу роль у цьому процесі відіграє спецкурс. Однак це не означає, що він обов'язково має бути виділений в окремий предмет. Контекстні основи спецкурсу можуть застосовуватися, наприклад, у курсі «Аналіз музичних творів» як навчання музиканта розу- 
мінню і осмисленню цілісного процесу розвитку музичного мистецтва.

Завдання полягало в поетапному навчанні студентів музичному мисленню в процесі взаємодії з предметами дослідження. Основи цього мислення починали закладатися на практичних заняттях 3 аналізу музичних творів. Потім сформовані вміння отримували свій подальший розвиток у процесі вивчення спецкурсу для магістрів «Методологія і технологія музичного мислення особистості».

На першому занятті 3 аналізу музичних творів студентам давалась установка на необхідність формування музичного мислення, розкривалось його значення для оволодіння ціннісно-методологічної культурою особистості педагога-музиканта. Починаючи з другого заняття і закінчуючи восьмим, здійснювалось навчання прийомів дослідження музичного процесу, а також фактів, явищ, обставин, ситуацій, що його позначають. Дев’яте-п'ятнадцяте заняття були відведені для тренінгу із взаємодії з предметами музичного дослідження. Наступним етапом було вивчення магістрами цілісного процесу дослідження музичного мистецтва в ході спецкурсу «Методологія і технологія музичного мислення особистості». Зміст зазначеного спецкурсу спрямовувався на формування і розвиток музичного мислення магістрів. У результаті майбутні музиканти отримували необхідні знання з будови структури музичного мислення, ознайомлювалися 3 рефлексивною моделлю управління процесом його формування, виводили самостійні й незалежні судження під час вирішення проблем музичного дослідження.

У ході аналізу музичних творів та читання спецкурсу здійснювалася систематична робота 3 діагностики індивідуальних можливостей студентів щодо виявлення ступеня сформованості й розвитку в них музичного мислення.

Формування музичного мислення у майбутніх музикантів вимагало залучення останніх до аналізу, синтезу, оцінювання, узагальнення, самостійних, незалежних висновків. Ми звернули увагу на той факт, що навіть ті студенти, які при аналізі фактів, явищ, обставин взаємодії 3 предметами музичного дослідження, виводили довгі дедуктивні ланцюжки, складні для розуміння теоретичні конструкції, застосовували стандартні, фундаментальні за значенням, невеликі за кількістю ментальні акти, що становлять вміння вибирати мету дослідження, розробляти тактику відношень цілісного музичного процесу. Причому основоположним принципом у пізнанні була єдність раціональності й творчості, зумовлених розсудливою і творчо перетворювальною діяльністю майбутніх музикантів. Реалізація цього принципу свідчила про усвідомлення студентами значення ідей, суджень, умовиводів, виражених у загальному, опосередкованому й професійному видах.

У межах своїх міркувань майбутні музиканти розташовували послідовність своїх пізнавальних актів, створюючи струнку систему відношень у процесі взаємодії з предметами музичного дослідження. Це було пов'язано 3 тим, що в ході такого дослідження вони могли допускати, припускати, порівнювати, доходити висновків, протиставляти, дедукувати, або індукувати, класифікувати, описувати, визначати або пояснювати, тобто виробляти доцільну стратегію і тактику. При цьому у тих, хто навчався музичного мислення, зростала кількість знайдених ознак спостережуваних об'єктів, суб'єктів, фактів, явищ, обставин як суттєвих, типових, так і несуттєвих, нетипових. Виявлялись ознаки якісно нового типу, які узагальнювалися в поняття, часткові визначення, спрямовані на реалізацію задуманої стратегії і тактики дослідження. Скоротився розрив між аналізами однієї і тієї ж обставини розвитку музичного мистецтва, які мали спочатку діаметрально протилежні позиції. Зросла впевненість в істинності теоретичних положень, які використовувалися при дослідженні системи відношень цілісного музичного процесу. Виробилось уміння застосовувати знання в нових конкретних ситуаціях дослідження. Судження майбутніх музикантів стали більш визначеними і доказовими.

Разом $з$ тим було виявлено, що деякі студенти, вміючи виокремлювати ознаки спостережуваних фактів, класифікувати їх на суттєві й несуттєві, мали труднощі у встановленні причинно-наслідкових, інструментально-самодостатніх відношень та відношень «частин цілого» між ними. У результаті ж оволодіння технологією музичного мислення вони могли не тільки констатувати виявлені факти та їх ознаки, а й встановлювати між ними взаємозв'язки й взаємозалежності. Окрім того, став вищим загальний рівень сформованості музичного мислення випускників, що пояснюється більшою систематичністю, послідовністю, безперервністю занять студентів на денному навчанні, оволодінням знаннями законів і закономірностей, узагальненими професійними вміннями, набуттям досвіду в процесі дослідницької самокритичної діяльності.

Висновки. Залучення майбутніх музикантів до дослідницької самокритичної діяльності, 
реалізація рефлексивного управління процесом формування музичного мислення $€$ основою значних позитивних зрушень у рівнях сформованості останнього. Крім того, зріс коефіцієнт кореляції між експертними оцінками і самооцінками рівнів сформованості музичного мислення студентів. У цілому аналіз ступеня розвитку музичного мислення у майбутніх музикантів у результаті участі в дослідницькій діяльності засвідчив їхню велику адаптованість до процесу формування зазначеного мислення. Остання виявилася в тому, що студенти більш гнучко, плавно й оперативно справлялись з виділенням складних проблем, їх розв'язанням у контексті музичного дослідження. Характерним стало прагнення майбутніх музикантів структурувати свою дослідницьку діяльність як серію розумових кроків, операцій, умінь. Слід віддати належне тому, що навіть ті студенти, які застосовували примітивні пізнавальні кроки (за умови чіткої послідовності й стратегічної організації останніх), досягали високих результатів у дослідницькій діяльності. Хоча набір використаних пізнавальних умінь не відрізнявся різноманітністю й був подібними для більшості студентів, їхнє музичне мислення вирізнялося багатством стратегічних і тактичних підходів до аналізу музичних фактів, явищ, обставин за рахунок творчого створення нових технологічних методів і прийомів дослідження.

У ході навчання музичному мисленню ми реалізовували методи, що давали змогу вивчити весь повномасштабний обсяг різноманітних розумових операцій і вмінь, які майбутні музиканти застосовували у своїй дослідницькій самокритичній діяльності. Тому ті студенти, які швидше досягали достатніх результатів у сформованості свого музичного мислення, надалі виявляли більш високий рівень самоуправління процесом формування музичного мислення особистості. Зокрема, у формуванні останнього велику роль зіграло оволодіння ними логічними елементами, так само як і перетворення логічних операцій у контексті цілісного процесу музичного дослідження.

Таким чином, якщо рефлексивне управління процесом формування музичного мислення сприяло розвитку розсудливої і творчої індивідуальності, то рефлексивне моделювання цілісного процесу музичного дослідження дало змогу організувати самоуправління особистості майбутнього музиканта. При цьому давалась установка на розвиток діалогічного мислення, актуалізацію незалежності й самостійності професійних ідей, суджень, умовиводів, активізацію самокритики і пріоритет вирішення склад- них проблем. Формування такого незалежного, самостійного мислення музиканта здійснювалося на базі полісуб'єктного підходу, що полягає в тому, що всі учасники дорадчого музичного дослідження займали стосовно одне одного суб'єктну позицію. Тобто особистість представлялась як унікальна сутність і головна цінність освітнього процесу на основі реалізації принципу єдності індивідуального й соціального.

3 огляду на сказане можна констатувати, що застосування рефлексивного управління цілісним процесом музичного дослідження забезпечило підвищення ефективності реалізації особистісно-діяльнісного підходу до студентів у ході формування у них музичного мислення, дало змогу досягти мети формування останнього - оволодіти професійною розумністю музиканта, розвитком розсудливої і творчої індивідуальності, автономії особистості. Відчувши доброзичливе ставлення до себе як до особистості, яка має право на самостійну, незалежну точку зору, студенти виявляли впевненість у собі як музиканти. Вони знали, що будь-яке їхє прагнення, бажання зрозуміти й осмислити цілісний процес музичного дослідження будуть заохочені незалежно від того, необхідні їхні альтернативні думки чи ні.

Як результат проведеного дослідження, були виведені закономірності реалізації особистісно-діяльнісного підходу до студентів музичних вишів у процесі формування у них музичного мислення:

- підвищення ефективності реалізації особистісно-діяльнісного підходу до студентів у ході формування у них музичного мислення залежить від ступеня впровадження рефлексивного управління цілісним процесом музичного дослідження;

- досягнення мети і результату формування музичного мислення - оволодіння професійною розумністю музиканта - визначається ступенем ефективності реалізації особистісно-діяльнісного підходу в процесі формування у майбутніх музикантів зазначеного мислення.

Дискусія. Разом з тим при аналізі здобутків дослідження було виявлено й деякі проблеми, які потребують вирішення. Зокрема, це стосується невеликої кількості студентів, які, незважаючи на залучення їх до дослідницької діяльності, продемонстрували не найкращий рівень сформованості музичного мислення або ж їхній рівень розвитку професійної розумності залишався незмінним. Тому виникла проблема визначити причину такого явища. Інакше кажучи, слід було з'ясувати, чому дослідницька діяльність майбутніх музикантів 3 низьким, 
недостатнім рівнем сформованості музичного мислення не розвиває, а призупиняє рух їхньої пізнавальної діяльності. У ході дорадчого дослідження студенти, які брали участь в діалогічному спілкуванні, дійшли думки про те, що однією з причин низького рівня сформованості у них музичного мислення є недостатня розвиненість останнього в шкільні роки. Ми не виключаєм резонність такого зауваження, але слід звернути увагу і на той факт, що в повсяк- денному житті майбутні музиканти міркують досить добре, а в академічному — явно відстають. Отже, на професійні міркування студентів музичних 3ВО, крім дослідницької діяльності, впливає низка інших факторів, що визначають їхнє професійне мислення. Виявлення цих чинників і ступеня їх впливу на сформованість музичного мислення майбутніх музикантів складає чергову проблему, яку надалі необхідно вивчати.

\section{ДЖЕРЕЛА}

1. Абдуллин Э.Б. Основы исследовательской деятельности педагога-музыканта: учеб. пособ. СПб.: Изд-во «Лань»; Изд-во «ПЛАНЕТА МУЗЫКИ», 2014. 368 с.

2. Краткий психологический словарь / сост. Л.А. Карпенко; под общ. ред. А.В. Петровского, М.Г. Ярошевского. М.: Политиздат, 1985. 431 с.

3. Москаленко В.Г. Лекции по музыкальной интерпретации: учеб. пособ. К.: Изд-во ТОВ «Типографія “Клякса"», 2013. 272 с.

4. Падалка Г.М. Педагогіка мистецтва (Теорія і методика викладання мистецьких дисциплін). К.: Освіта України, 2010. 274 с.

5. Сопер П. Основы искусства речи; [пер. с англ.]. 2-е изд. испр. М.: Прогресс-Академия, 1992. 416 с. 6. Философский энциклопедический словарь / редкол.: С.С. Аверинцев, Э.А. Араб-Оглы, Л.Ф. Ильчев и др. 2-е изд. М.: Советская энцикл., 1989. 815 с.

7. Цагарелли Ю.А. Психология музыкально-исполнительской деятельности: учеб. пособ. СПб.: Композитор, 2008. 368 с.

\section{REFERENCES}

1. Abdullin, E. B. (2014). Osnovy issledovatelskoi deiatelnosti pedagoga-muzykanta: uchebnoie posobie. SPb.: Izdatelstvo «Lan»; Izdatelstvo «PLANETA MUZYKI», 368 p. (in Russian).

2. Kratkii psikhologicheskii slovar. (1985). Sost. L. A. Karpenko; Pod obshch. red. A.V. Petrovskogo, M. G. Yaroshevskogo, M.: Politizdat, 431 p. (in Russian).

3. Moskalenko, V. G. (2013). Lektsii po muzykalnoi interpretatsii: Uchebnoie posobie. K.: Izdatelstvo TOV «Tipografiia "Kliaksa"», 272 p. (in Russian).

4. Padalka, H. M. (2010). Pedahohika mystetstva (Teoriia i metodyka vykladannia mystetskykh dystsyplin). K.: Osvita Ukrainy, 274 p. (in Ukrainian).

5. Soper, P. (1992). Osnovy iskusstva rechi. Per. s angl., 2-e izd. ispr., M.: Progress-Akademiia, 416 p. (in Russian).

6. Filosofskii entsiklopedicheskii slovar. (1989). Redkol.: S. S. Averintsev, E. A. Arab-Oglyi, L. F. Ilchev i dr., 2-e izd., M.: Sov. Entsiklopediia, 815 p. (in Russian).

7. Tsagarelli, Yu. A. (2008). Psihologiia muzykalno-ispolnitelskoi deiatelnosti. Uchebnoie posobie, SPb.: «Kompozitor», 368 p. (in Russian).

\section{Нагорная Г.О. \\ ИССЛЕДОВАТЕЛЬСКАЯ ДЕЯТЕЛЬНОСТЬ КАК ФАКТОР ФОРМИРОВАНИЯ МУЗЫКАЛЬНОГО МЫШЛЕНИЯ ЛИЧНОСТИ}

В статье освещена проблема организации исследовательской деятельности студентов музыкальных вузов как главного фактора, влияющего на сформированность их музыкального мышления. Для достижения этой чели осуществлялось преобразование музыкального образования как целостного процесса музыкального исследования на основе рефлексивного моделирования, а музыкального исследования как исследовательской самокритической деятельности музыканта. Было установлено, что только при системном изучении будущими музыкантами фактов, явлений, обстоятельств музыкального процесса возможно выработать обобщенные умения определять и достигать чели музыкального исследования, вырабатывать иенностно-методологическую стратегию и тактику отношений в процессе взаимодействия с предметами этого исследования, самооценивать результаты своей исследовательской деятель- 
ности. Помимо этого, формирование музыкального мышления личности направлялось на достижение ею профессиональной разумности как универсального качества, обеспечивающего понимание и осмысление целостного процесса музыкального исследования и обуславливающего овладение ченностно-методологической культурой.

Ключевые слова: исследовательская деятельность, личностно-деятельностный подход, музыкальное мышление, профессиональная разумность, рефлексивное управление.

\section{G. Nagorna}

\section{RESEARCH ACTIVITIES AS FORMATION FACTOR OF MUSICAL THINKING OF PERSONALITY}

The article reveals the problem of organizing research activities of students of musical universities as the main factor influencing the formation of their musical thinking. To achieve this goal, music education is transformed as a holistic process of musical research based on reflexive modeling, and musical research as a musician's self-critical research activity. It is found that only in a systematic study by future musicians of facts, phenomena, circumstances of the musical process, it is possible to develop generalized skills to determine and achieve the goal of musical research, develop value-methodological strategy and tactics of relations in the process of interaction with the subjects of this research, self-assess the results of their research activities. In addition, development of musical thinking of personality is aimed at achieving its professional reasonableness as a universal quality, providing understanding and comprehension of the holistic process of musical research and determining mastering the value-methodological culture. In the process of the research, the following is undertaken: the methodology of the criterion-value approach is substantiated as the leading strategy of the personality-activity approach to students of music universities in the process of development of their musical thinking; the types of research activities (reasonable, organizational-informational, creatively transformative, evaluating) and their interrelation on the basis of the principles of unity of the universal and particular, simple and complex are revealed; the research selfcritical activity of the future musician is revealed as a criterion of the truth of his musical thinking, aimed at mastering the professional reasonableness of the individual; analysed the role of the reflexive control of the formation of musical thinking of the individual and the holistic process of musical research.

The involvement of future musicians in research self-critical activity, as well as the implementation of the reflexive control of the process of development of musical thinking, provided significant positive changes in the levels of development of this thinking. If reflexive management of the process of development of musical thinking contributed to the development of rational and creative individuality, then reflexive modeling of the holistic process of musical research made it possible to achieve self-management of the student's personality, which led to the development of dialogical thinking, actualization of the independence of professional ideas, judgments, inferences, activation of self-criticism, priority to solving complex problems.

As a result of the study, the appropriateness of the realization of the personality-activity approach to students of musical universities in the process of development of their musical thinking are derived: the increase in the effectiveness of the implementation of the personal-activity approach to students during the formation of their musical thinking depends on the degree of implementation of the reflexive management of the integral process of musical research; the achievement of the goal and result of the development of musical thinking - mastering professional reasonableness of a musician - is determined by the degree of effectiveness of the implementation of the personality-activity approach in the process of formation of the specified thinking with future musicians.

Key words: research activity, personal-activity approach, music thinking, professional reasonableness, reflexive management.

Стаття надійшла до редакції 10.12.2018.

Прийнято до друку 14.12.2018. 